\title{
The Influence of Experiential Marketing and Relationship Marketing on Hotel Customer Loyalty
}

Estikowati $^{1}$, Widji Astuti* ${ }^{1}$ and Harianto Respati ${ }^{1}$

Iniversity of Merdeka Malang, Indonesia
Article History
Received: 15.08 .2020
Accepted: 08.09 .2020
Published: 30.09 .2020
Journal homepage:
https://www.easpublisher.com/easjebm
Quick Response Code

Abstract: The research objectives, describe experiential marketing, relationship marketing, customer satisfaction and customer loyalty, analyze the effect of experiential marketing and relationship marketing on hotel customer satisfaction, analyze the effect of experiential marketing and relationship marketing on customer loyalty, analyzing the effect of experiential marketing and relationship manager on hotel customer loyalty through customer satisfaction, this research was conducted in a 3-star hotel in Malang Raya. The research design was carried out with a quantitative approach, and data collection techniques were carried out by distributing questionnaires. Technical analysis of data structural equation modelling with AMOS 21 software application. Determination of the sample in the analysis of Structural Equation Model (SEM) according to slovin with an error rate of $5 \%-10 \%$ with the formula obtained the number of respondents of 130 people. The results showed, the experiential marketing and relationship marketing affect customer loyalty and customer satisfaction affects customer loyalty, experiential marketing and relationship marketing affects customer loyalty through customer satisfaction. The contribution of this research is expected to enrich the theory of marketing strategies in the hospitality sector in maintaining customer loyalty. For hotel management, it can be used as a reference for improving marketing strategies and human resources in increasing room occupancy by building relationship marketing and experiential marketing.

Keywords: experiential marketing, relationship marketing, customer satisfaction, customer loyalty.

Copyright @ 2020: This is an open-access article distributed under the terms of the Creative Commons Attribution license which permits unrestricted use, distribution, and reproduction in any medium for non-commercial use (Non-Commercial or CC-BY-NC) provided the original author and source are credited.

\section{INTRODUCTION}

The tourism industry is growing and developing every year. The development of the number of accommodation is also getting higher which is expected to be able to increase the number of tourists coming and staying to enjoy the holiday period. To anticipate the number of tourists who are currently growing rapidly, facilities and infrastructure are needed, one of which is a hotel, because accommodation is important for tourists. This implies, management competes to offer the concept and experience of staying to hotel guests.

In order to meet the needs of the travellers' staying experience, hotels provide various types of lodging based on the classification which is divided into star and non-star hotels. Based on data from BPS in 2019, 3-star hotels have the largest number, namely $1302(39.29 \%)$ of the total number of star hotels.

For hotel owners and managers to be able to survive and run a business, loyal customers are needed so that they can commit to maintaining and marketing what the hotel offers. Mowen and Minor (1998) state that loyalty is a feeling of pleasure and commitment to the brand and will make purchases in the future. Various ways and stages are needed so that customers are loyal, in addition to management being creative, innovative, and using the latest technology, it must also be able to show the advantages of the hotel over others. Research by Jesri et al. (2013), show that all components of relationship marketing in terms of trust and commitment have a positive impact on customer loyalty. Customer loyalty occurs when customers experience a stay and a relationship with the company is built. The experience of staying that is felt is in accordance with expectations or more, so the customer gets satisfaction (Kotler and Keller, 2007). Customer satisfaction is influenced by experiential marketing (Wijaya et al: 2014), also influenced by relationship marketing (Oztruk: 2015).

\section{Literatur Review}

Some experts suggest customer loyalty indicators (Kotler and Keller, 2009: 157), (Griffin, 2002: 31) state that these indicators consist of repeat purchases (loyalty to product purchases), retention 
(resistance to negative influences on the company), and referrals (referencing the total essence of the company). Customer satisfaction is basically related to the level of a person's feelings after comparing the performance or results that customers feel with their expectations (Kotler and Keller, 2013: 138-139), customer satisfaction is the feeling of a customer who is satisfied or disappointed with the results of comparing the perceived performance of the product or results in relation to customer expectations.

Relational marketing according to Chan (2003: 6 ) is the introduction of each customer more closely by creating two-way communication by managing a mutually beneficial relationship between the customer and the company. Morgan and Hunt (1994: 36), state that trust is an important issue in establishing a cooperative relationship and is the basis for the continuation of a relationship that requires the willingness of customers to rely on companies that are partners. Commitment is very much influenced by trust. Trust is a belief in the reliability and integrity of an exchange partner.

Schmitt (1999, 53-67) states that in order to approach, gain, and retain loyal customers, producers through their products need to provide unique, positive, and memorable experiences to consumers. Experiential Marketing is a process of offering products and services by marketers to consumers by stimulating consumer emotions which results in various experiences for consumers (Schmitt, 1999: 60), further Schmitt $(1999,65)$ and Smilansky (2009: 5), dividing experiential types marketing into five dimensions, namely sensory experience (sense); affective experience (feel); creative cognitive experience (think); physical experience, behaviour and lifestyle (act); and socioidentity experiences resulting from a relationship with a reference community or culture (relate).

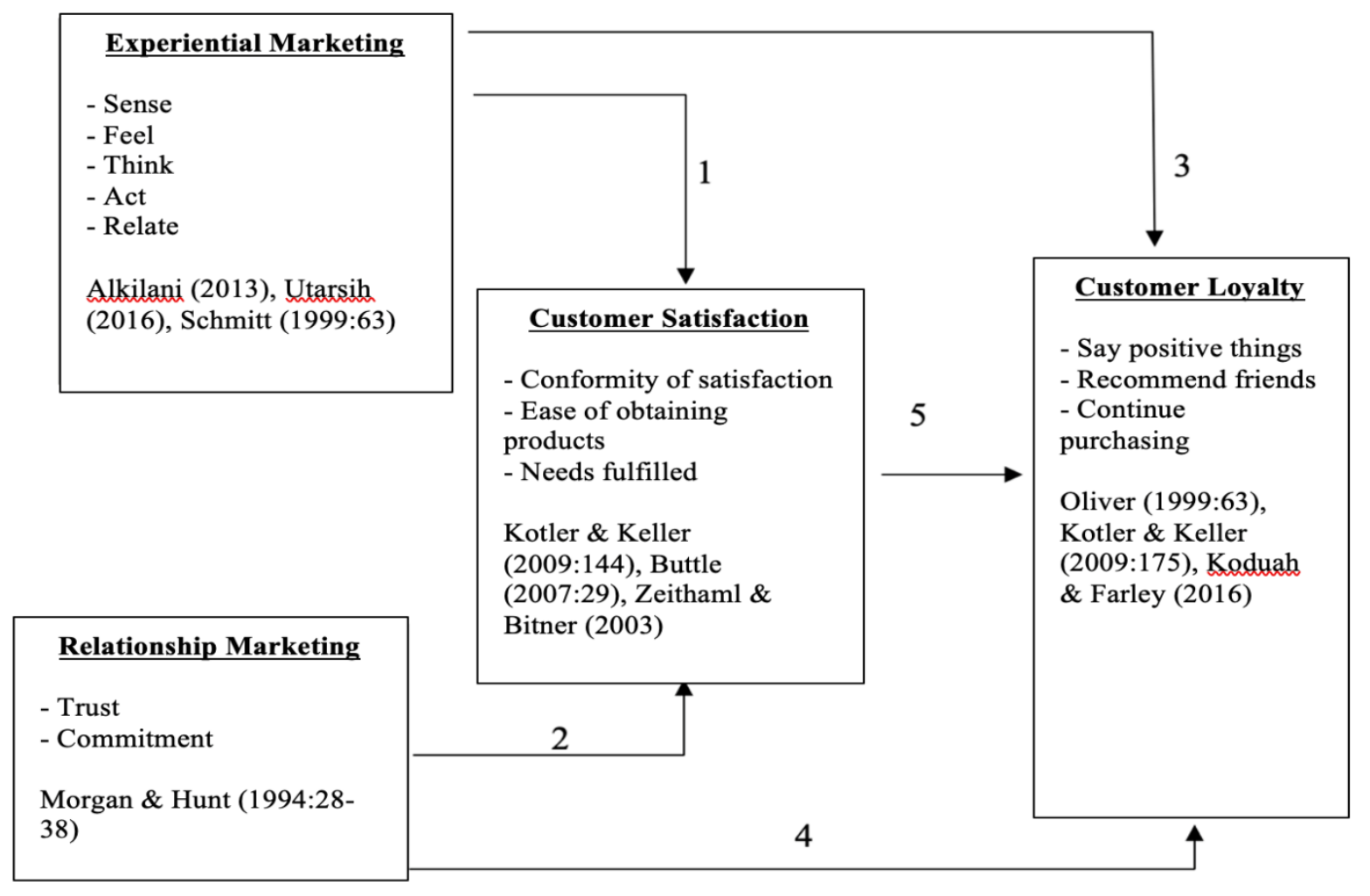

Figur 1. Conceptual Frame

\section{Research Hypothesis}

H1: Experiential marketing and relationship marketing have a positive and significant effect on hotel customer satisfaction

H2: Experiential marketing and relationship marketing have a positive and significant effect on hotel customer loyalty

H3: Hotel customer satisfaction has a positive and significant effect on hotel customer loyalty
H4: Experiential marketing and relationship marketing have a significant effect on hotel customer loyalty through hotel customer satisfaction

\section{RESEARCH METHODS}

This research is an explanatory research. This study uses four variables, namely experiential marketing, relationship marketing, customer satisfaction, and customer loyalty which are explored 
using a survey of customer opinions who stay at threestar hotels in Malang Raya for two days and one night.

The population in this study were all 54.796 three-star hotels in Malang Raya (PHRI, 2019; Dinas Pariwisata 2019). The sample in this study was taken by purposive sampling with the criteria that guests who had and were staying at the hotel at least two days and one night at the time of the study were at least 17 years old, and were able to fill out a questionnaire. To determine the number of samples used the Slovin formula with an error rate of 5\% - 10\% in order to obtain 130 respondents. Data from the questionnaire will be processed and analysed descriptively using the SEM method.

\section{RESEARCH RESULT}

\section{SEM Analysis}

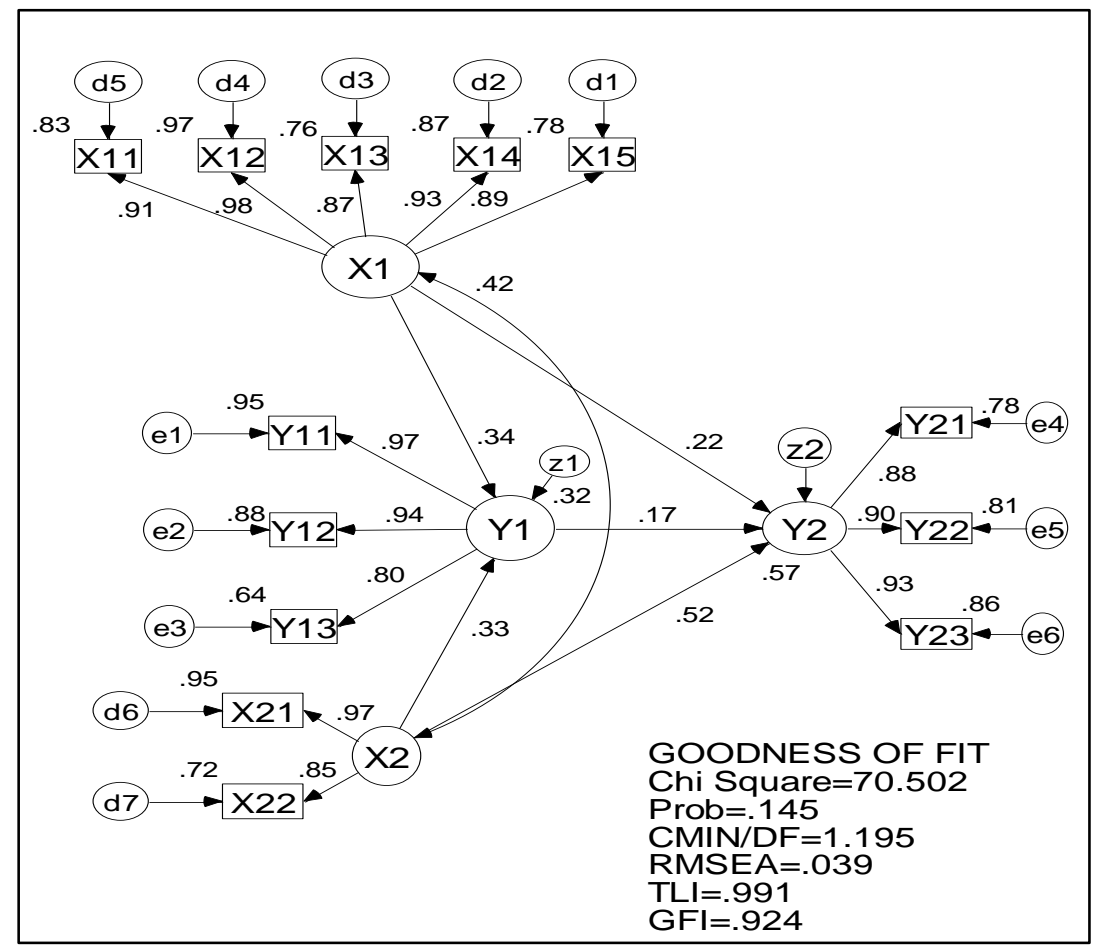

Figur 2. Structural Equation Model

Rejection or acceptance of the Structural Equation Model which is shown in Figure 9, as an analysis tool appears on the resulting Goodness of fit indexs value. The criteria for acceptance of the structural equation model will be compared with the recommended cut-off values.

\section{Validity Test}

Table 1.The results of the validity test of the exogenous variable X1 size model

\begin{tabular}{|c|c|c|c|c|c|}
\hline Indicator & $\begin{array}{c}\text { Variabel } \\
\text { Latent }\end{array}$ & $\begin{array}{l}\text { Loading } \\
\text { Factor }\end{array}$ & CR & $\begin{array}{c}P \\
\text { Value }\end{array}$ & Note \\
\hline Sense & Experiential Marketing & 0.91 & 15,450 & 0,000 & Valid \\
\hline Feel & Experiential Marketing & 0.99 & 18,669 & 0,000 & Valid \\
\hline Think & Experiential Marketing & 0.87 & Fixed & 0,000 & Valid \\
\hline Act & Experiential Marketing & 0.93 & 16,402 & 0,000 & Valid \\
\hline Relate & Experiential Marketing & 0.89 & 14,575 & 0,000 & Valid \\
\hline Trust & Experiential Marketing & 0.97 & 11,536 & 0,000 & Valid \\
\hline Commitment & Experiential Marketing & 0.85 & Fixed & 0,000 & Valid \\
\hline $\begin{array}{l}\text { Reliab } \\
\text { Varian }\end{array}$ & $\begin{array}{l}\text { Construct } \\
\text { Extract }\end{array}$ & \multicolumn{3}{|c|}{ (cut-off value $=0,7)$} & $\begin{array}{c}\text { Reliabel } \\
\text { Valid }\end{array}$ \\
\hline
\end{tabular}

Source: Primary data processed, 2019 
a. Based on Table 1 shows that the value of the factor loading for each indicator exceeds the standard cut-off value of 0.5 , the probability value $(\mathrm{p})$ is less than or equal to 0.05 , the Reliability Construct value is 0.974 greater than the standard cut-off value of 0,7 and the
Variance Extract value of 0.841 is greater than the standard cut-off value of 0.5 . The results of this test indicate that the indicators tested have good reliability in forming and operationalizing the latent variables of Experiential Marketing and Relationship Marketing.

Table 2. Results of the Validity Test of Intervening and Endogenous Variables

\begin{tabular}{|c|c|c|c|c|c|}
\hline Indicator & $\begin{array}{l}\text { Variabel } \\
\text { Latent }\end{array}$ & $\begin{array}{l}\text { Loading } \\
\text { Factor }\end{array}$ & $\mathbf{C R}$ & $\begin{array}{c}\mathbf{P} \\
\text { Value }\end{array}$ & Note \\
\hline Hope Suitability & $\begin{array}{c}\text { Customer } \\
\text { Satisfaction }\end{array}$ & 0.97 & 22,316 & 0,000 & Valid \\
\hline Ease of Obtaining Products & $\begin{array}{l}\text { Customer } \\
\text { Satisfaction }\end{array}$ & 0.94 & Fixed & 0,000 & Valid \\
\hline Needs Fulfilled & $\begin{array}{c}\text { Customer } \\
\text { Satisfaction }\end{array}$ & 0.80 & 13,348 & 0,000 & Valid \\
\hline Saying Positive Things & Customer Loyalty & 0.88 & Fixed & 0,000 & Valid \\
\hline Recommend Friends & Customer Loyalty & 0.90 & 14,805 & 0,000 & Valid \\
\hline Continue Purchasing & Customer Loyalty & 0.93 & 15,610 & 0,000 & Valid \\
\hline $\begin{array}{l}\text { Reliability Construct } \\
\text { Variance Extract }\end{array}$ & $\begin{array}{l}=0,964 \\
=0,819\end{array}$ & $\begin{array}{l}\text { (cut-off } \\
\text { (cut-off }\end{array}$ & $\begin{array}{l}\text { lue }=0,7) \\
\text { lue }=0,5)\end{array}$ & & $\begin{array}{c}\text { Reliabel } \\
\text { Valid }\end{array}$ \\
\hline
\end{tabular}

Source: Primary data processed, 2019

b. Based on the information in Table, it shows that the value of the loading factor for each indicator exceeds the standard cut-off value of 0.5 , the probability value (p) is less than or equal to 0.05 , the Reliability Construct value of 0.964 is greater than the standard cut-off value of 0.7 and the Variance Extract value of 0.819 is greater than the standard cut-off value of 0.5. The results of this test show that the indicators of customer satisfaction are: Suitability of Expectations, Ease of Acquiring Products, Needs Fulfilled and Customer Loyalty with indicators of Saying Positive Things, Recommending Friends, and Continue Purchasing which are tested in fact have good reliability in forming and operating variables. latent customer satisfaction and customer loyalty.

\section{Hypothesis Test Results First Hypothesis}

Table 3. The effect of experiential marketing and relationship marketing on customer satisfaction

\begin{tabular}{|c|c|c|c|c|c|c|c|}
\hline $\begin{array}{c}\text { Exogenous } \\
\text { Variable }\end{array}$ & $\begin{array}{c}\text { Intervening } \\
\text { Variable }\end{array}$ & $\begin{array}{c}\text { Standardized } \\
\text { Regression } \\
\text { Weight }\end{array}$ & Estimate & S.E. & C.R. & $\mathbf{P}$ & note \\
\hline $\begin{array}{c}\text { Experiential } \\
\text { marketing }\end{array}$ & $\begin{array}{c}\text { Customer } \\
\text { Satisfaction }\end{array}$ & 0,34 & 0,417 & 0,108 & 3,875 & 0,004 & Tested \\
\hline $\begin{array}{l}\text { Relationship } \\
\text { marketing }\end{array}$ & $\begin{array}{l}\text { Customer } \\
\text { Satisfaction }\end{array}$ & 0,33 & 0,377 & 0,102 & 3,683 & 0,000 & Tested \\
\hline
\end{tabular}

Source: Primary data processed, 2019.

Table 3, the critical ratio (CR) of experiential marketing and relationship marketing shows that it is greater than 2 and the $\mathrm{P}$ value ( $\mathrm{P}$-value) of 0.0000 is smaller or equal to 0.05 . In the form of standardized regression weight for experiential marketing has a significant effect on customer satisfaction (0.34).
Relationship marketing has a significant effect on customer satisfaction in the form of a standardized regression weight with a value of 0.33 , so experiential marketing and relationship marketing have a positive and significant effect on customer satisfaction, so the first hypothesis is accepted. 


\section{Second hypothesis}

Table 4.The influence of experiential marketing and relationship marketing on customer loyalty

\begin{tabular}{lccccccc}
\hline \multicolumn{1}{c}{$\begin{array}{c}\text { Exogenous } \\
\text { Variable }\end{array}$} & $\begin{array}{c}\text { Endogenous } \\
\text { Variable }\end{array}$ & $\begin{array}{c}\text { Standardized } \\
\text { Regression } \\
\text { Weight }\end{array}$ & Estimate & S.E. & C.R. & P & Note \\
\hline $\begin{array}{l}\text { Experiential } \\
\text { marketing }\end{array}$ & $\begin{array}{c}\text { Customer } \\
\text { Loyalty }\end{array}$ & 0,22 & 0,191 & 0,068 & 2,809 & 0,005 & Tested \\
$\begin{array}{l}\text { Relationship } \\
\text { marketing }\end{array}$ & $\begin{array}{c}\text { Customer } \\
\text { Loyalty }\end{array}$ & 0,52 & 0,424 & 0,07 & 6,077 & 0,000 & Tested \\
\hline
\end{tabular}

Source: Primary data processed, 2019.

Table 4 shows that the CR from experiential marketing and relationship marketing shows greater than 2 and the $\mathrm{P}$ value (P-value) of 0.0000 is smaller or equal to 0.05 . In the form of standardized regression weight for experiential marketing has a significant effect on customer loyalty with a value of 0.22 .
Relationship marketing has a significant effect on customer loyalty in the form of standardized regression weight with a value of 0.52 . Thus, experiential marketing and relationship marketing have a positive and significant effect on customer satisfaction, so the second hypothesis is accepted.

\section{Third hypothesis}

Table 5. Test Results of the Effect of Customer Satisfaction on Customer Loyalty.

\begin{tabular}{|c|c|c|c|c|c|c|c|}
\hline $\begin{array}{c}\text { Intevening } \\
\text { Variable }\end{array}$ & $\begin{array}{c}\text { Endogenous } \\
\text { Variable }\end{array}$ & $\begin{array}{c}\text { Standardized } \\
\text { Regression } \\
\text { Weight } \\
\end{array}$ & Estimate & S.E. & C.R. & $\mathbf{P}$ & Note \\
\hline $\begin{array}{l}\text { Customer } \\
\text { Satisfaction }\end{array}$ & $\begin{array}{l}\text { Customer } \\
\text { Loyalty }\end{array}$ & 0,17 & 0,119 & 0,058 & 2,046 & 0,041 & Tested \\
\hline
\end{tabular}

Source: Primary data processed, 2019

Table $5 \mathrm{CR}$ of experiential marketing and relationship marketing shows that it is greater than 2 and the $\mathrm{P}$ value (P-value) of 0.0000 is smaller or equal to 0.05 , because the probability obtained is 0.041 (less than 0.05). The direction and magnitude of the standardized direct effect coefficient is 0.17 . The results of this test indicate that customer satisfaction has a significant effect on customer loyalty. Thus the third hypothesis is statistically tested.

The fourth hypothesis

Table 6. Causality Relationship Between Research Variables.

\begin{tabular}{lcccccc}
\hline \multicolumn{1}{c}{$\begin{array}{c}\text { Exogenous } \\
\text { Variable }\end{array}$} & $\begin{array}{c}\text { Intervening } \\
\text { Variable }\end{array}$ & $\begin{array}{c}\text { Endogenous } \\
\text { Variable }\end{array}$ & $\begin{array}{c}\text { Direct } \\
\text { Effects }\end{array}$ & $\begin{array}{c}\text { Indirect } \\
\text { Effects }\end{array}$ & $\begin{array}{c}\text { Total } \\
\text { Effects }\end{array}$ & Note \\
\hline $\begin{array}{l}\text { Experiential } \\
\text { marketing }\end{array}$ & $\begin{array}{c}\text { Customer } \\
\text { Relationship }\end{array}$ & Customer loyalty & 0,22 & 0,06 & 0,28 & Tested \\
marketing & $\begin{array}{c}\text { Customer } \\
\text { satisfaction }\end{array}$ & Customer loyalty & 0,52 & 0,06 & 0,58 & Tested \\
\hline
\end{tabular}

Source: Primary data processed, 2019

Table 4 shows that the total effect of experiential marketing 0.28 is greater than the direct effect of experiential marketing 0.22. Relationship marketing, the total effect of 0.58 is greater than the direct effect of 0.52 , so that customer satisfaction is tested as an intervening variable that mediates relationship marketing and experiential marketing on customer loyalty.

\section{DISCUSSION OF RESEARCH RESULTS}

The research was conducted in 2019 where there has not been a Covid-19 pandemic which has been able to change basic human behaviour regarding the economy and health so that travel has not linked the situation and impact of the Covid-19 pandemic in generating customer satisfaction and bringing customer loyalty.

Experiential Marketing and Relationship Marketing Affect Customer Satisfaction 
Experiential marketing affects customer satisfaction. The results of the study are in line with Alkialani (2013), Wijaya \& Subagyo (2014), Christiana Damayanti (2013), Chao (2015), Ozruk (2015). The experiential marketing indicator that gives the biggest contribution to increasing customer satisfaction is the feel, which is reflected in the friendly hotel employees serving. Experiential marketing and relationship marketing have an effect on customer satisfaction, experiential marketing has a greater influence on customer satisfaction than relationship marketing even though the two variables have the same effect on customer satisfaction.

Experiential marketing has a dominant effect on customer satisfaction at three-star hotels in Malang Raya. The results showed that experiential marketing has a major contribution in the form of feel, which means that employees are friendly in serving and guests immediately receive service. During their stay at the hotel, customers prefer to be with their family to build more intimacy and plan to stay with customers for more than one night.

Relationship marketing affects customer satisfaction. The results of the study are as found by Rizan (2014). The customer marketing experience served by friendly employees gives a binding feeling to the hotel and the comfort obtained during the stay makes you believe that the hotel meets the needs of the customer in the stay so that the customer feels satisfaction.

\section{Experiential Marketing and Relationship Marketing Affect Customer Loyalty}

Experiential marketing, which is reflected in feel, has an effect on customer loyalty to continue purchasing, by adding more days to stay or extending stay. Loyalty shows the tendency of customers to use hotel services and facilities with a high level of consistency.

Relationship Marketing, which is reflected in the attitude of trust, has an effect on customer loyalty to continue to purchase, by adding more days to stay or extending stay. Relationship marketing creates relationships and more attention to customers in retaining hotel customers. The results of the research by Jesri, Ahmadi, Fatehipoor (2013), Husnain (2015), and Rizan (2014) prove that relationship marketing has an effect on customer loyalty.

\section{Customer Satisfaction Affects Customer Loyalty}

The results of research on customer satisfaction affect customer loyalty at three star hotels in Malang Raya indicate that customer satisfaction has a positive and significant effect on customer loyalty at three star hotels in Malang Raya, this study agrees with Christiana and Dharmayanti's (2013) research that customer satisfaction has a positive and significant effect on customer loyalty, this is in line with the research of Wijaya and Dharmayanti (2013) and Farhana (2018) that increasing customer satisfaction can increase customer loyalty. The convenience of guests in obtaining the desired product at each outlet provides its own value for guests, thus affecting customer loyalty in terms of continuing purchasing where guests will add more days to stay at the same hotel.

\section{Experiential Marketing and Relationship Marketing Affect Customer Loyalty through Customer Satisfaction}

Experiential marketing and relationship marketing have a positive and significant effect on customer loyalty through customer satisfaction at threestar hotels in Malang Raya. Experiential marketing variables have a stronger effect on customer loyalty if mediated by customer satisfaction, experiential marketing is based on five indicators, sense, feel, think, act and relate, the highest indicator is feel. This is consistent with research by Zena and Hadisumarto (2012) which states that experiential marketing has a stronger effect on customer loyalty if it is mediated by customer satisfaction.

Experiential marketing that is felt by customers in terms of hotel conditions that are clean and have a beautiful environment and relationship marketing built by hotels to customers where customers have a sense of trust because they feel comfortable meeting professional hotel employees. This has an impact on customer loyalty to continue purchasing by adding more days to stay.

\section{Conclusions AND Suggestions}

The effect of experiential marketing and relationship marketing on customer loyalty through customer satisfaction at three-star hotels in Malang Raya, which shows that experiential marketing and relationship marketing Ehave an influence on customer loyalty through customer satisfaction at 3-star hotels in Malang Raya. Relationship marketing affects customer loyalty if it is mediated by customer satisfaction. Relationship marketing, directly and indirectly, affects customer loyalty.

Based on the research results and conclusions that have been started, the suggestions put forward in this study are as follows: Theoretically, the hotel in this case management needs to maintain customer satisfaction by maintaining service quality and providing services according to guest expectations so that guests will indirectly become hotel marketing agents. Practically, improve relationship marketing, and the hotel should be committed to providing the best service at the right time. In order to increase customer satisfaction, the hotel should provide services by guest expectations. In order to increase customer loyalty, the hotel should provide services and provide facilities by 
what is offered, so that customers recommend it to others. Research limitations, the limitation of this study is that there are differences in respondents' perceptions in interpreting experiential marketing and relationship marketing that are felt when staying at a hotel. Next, this research was carried out when the world of tourism was normal before the Covid-19 pandemic I and now the Covid-19 pandemic has occurred so that there needs to be a review in similar research.

\section{REFERENCES}

1. Alkilani, K., Ling, K. C., \& Abzakh, A. A. (2013). The Impact of Experiential Marketing and Customer Satisfaction on Customer Commitment in the World of Social Networks. Asian Social Science, 9 (1). 2013.

2. Suharsimi, A. (1993). Prosedur Penelitian Suatu Pendekatan Praktik. Jakarta: Rineka Cipta Jakarta.

3. Henry, A. (1987). Costumer Behavior and Marketing Action. Boston: Keat Publishing Company.

4. Herni, J. A., \& Keisuke, N. (2014). Patient Loyalty to Health Care Organizations: Relationship Marketing and Satisfaction. International Journal of Management and Marketing Research, 7(2), 3956.

5. Manferd, B. (2003). Relationship Marketing: Management of Costumer Relasionship. Essex: Pearson Education.

6. Syafruddin, C. (2003). Relationship Marketing: Inovasi Pemasaran yang Membuat Pelanggan Bertekuk Lutut. Jakarta: PT Gramedia Pustaka Utama.

7. Chao, Ren-Fang. 2015. The Impact of Experimental Marketing on Customer Loyalty for Fitness Clubs: Using Brand Image and Satisfaction as the Mediating Variables. The Journal of International Management Studies, Vol.10 No. 2.P. 52

8. Christian, A., Dharmayanti, D. (2013). Pengaruh Experiential Marketing Terhadap Customer Satisfaction dan Customer Loyalty The Light Cup di Surabaya Town Square. Jurnal Manajemen Pemasaran Petra, 1 (2). P. 1-9 , Universitas Kristen Petra, Surabaya.

9. Churchill Jr, G. A., \& Surprenant, C. (1982). An investigation into the determinants of customer satisfaction. Journal of marketing research, 19(4), 491-504.

10. Waari, D. (2018). Loyalty Programs Benefits And Customer Loyalty Among Patrons of Star Rated Hotels In Kenya: A Moderated Mediation Model Of Experiential Encounter And Customer Satisfaction, International Journal of Economics, Commerce and Management United Kingdom VI (4), April 2018.

11. Futrell, C. M. (2000). ABC's Relationship Selling, International Edition 6th editions, The Mc GrawHill Companies, Singapore.
12. Ferdinand. (2002). Metode Penelitian Manajemen : Pedoman penelitian untuk Skripsi, Tesis, dan Desertasi Ilmu Manajemen, Semarang : Badan Penerbit Universitas Diponegoro

13. Fornell, C. (1992). A National Customer Satisfaction Barometer: The Swedish Experience. Journal of Marketing, 56.p 6-21

14. Gaspersz, V. 2002. Manajemen Kualitas dalam Industri Jasa. Jakarta: Gramedia Pustaka Utama.

15. Ghozali, I., \& Fuad. (2008). Structural Equation Modeling: Teori, Konsep, dan Aplikasi Dengan Program Lisrel 8.80 (2th ed.). Semarang: Badan Penerbit Universitas Diponegoro.

16. Griffin, J. (2002). Customer Loyalty: How to Earn it, How to Keep it. Lexington Books. New York: Avenue of Americas.

17. Hair, J.F., Thatam, R.L., Anderson, R.E., William, B. (1995). Multivariate Data Analysis with Reading, Fourth Edition, Prentice Hall. New Jersey

18. Christian, A., \& Dharmayanti, D. (2013). Pengaruh experiential marketing terhadap customer satisfaction dan customer loyalty the light cup di surabaya town square. Jurnal Manajemen Pemasaran Petra, 1(2), 1-13.

19. Utarsih, H. (2016). Pengaruh Experiental Marketing, Customer Customer Relationship Marketing, dan Customer Satisfaction terhadap Customer Loyalty Hotel Bintang 3 Sampai dengan 5 di Kota Bandung.; Jurnal Indonesia Membangun.15 (3), 115-138.

20. Holbrook, M. B., \& Hirschman, E. C. (1982). The experiential aspects of consumption: Consumer fantasies, feelings, and fun. Journal of consumer research, 9(2), 132-140.

21. Husnain, M., \& Akhtar, W. (2015). Relationship Marketing and Customer Loyalty: Evidence from Banking Sector in Pakistan. Global Journal of Management and Business Research : EMarketing, 15 (10), 1-14.

22. Jahromi, N. M., Adibzadeh, M., \& Nakhae, S. (2015). Examination the Interreltionship Experiential Marketing, Experiental Value, Purchase Behavior and Their Impact on Customers Loyalty (Case Study: Customers of Hormoz Hotel in Bandar-e-Abbas. Journal of Marketing and Consumer Research, 12. P 73-87

23. Jamal, A., \& Naser, K. (2002). Customer Satisfaction and Retail Banking: An Assessment of Some of the Key Antecedents of Customer Satisfaction in Retail Banking. International Journal of Bank Marketing, 20 (4), 146-160.

24. Jesri, P., Ahmadi, F., \& Fatehipoor, M. (2013). Effects of Relationship Marketing (RM) on Customer Loyalty (Case Study: Mehr Bank, Jermanshah Province, Iran). Interdisciplinary Journal of Contemporary Research in Business, 4(11), 304-312.

25. Hermawan, K. (2004). Marketing in Venus. Jakarta: Gramedia Pustaka Utama. 
26. Keisidou, E., Sarigiannidis, L., Maditinos, D., \& Thalassinos, I. E. (2013). Customer satisfaction, loyalty and financial performance: A holistic approach of the Greek banking sector in Marketing Intelligence and Planning, 31 (4), 259-288.

27. Kotler, P., \& Armstrong, G. (2009). Principle of Marketing. 13th Edition, Prentice Hall. Open Journal of Social Sciences, 4 (7), July 30, 2016

28. Koduah, E. Y., \& Farley, A. Y. D. (2016). Relationship between Customer Satisfaction and Customer Loyalty in the Retail Banking Sector of Ghana. International Journal of Business and Management, 11 (1), 249-262

29. Morgan, R.M., \& Hunt, S.D. (1994). The Commitment-Trust Theory of Relationship Marketing. Journal of Marketing, 58 (3), 20-38

30. Mowen, J. C., \& Minor, M. (1998). Consumer Behavior. New York: Prentice Hall Inc.

31. Sobari, N., Usman, H., \& Fadilla, T. (2019, November). Not As It May Seem: Quantitative Approach Explains Muslim Consumers Attitude Toward Personal Care Product. In 2nd International Conference on Strategic and Global Studies (ICSGS 2018). Atlantis Press.

32. Oliver, R. L. (1999). Whence Consumer Loyalty. Journal of Marketing, 63 Special Issue.P 33-44

33. Olsen, S.O. (2002). Comparative Evaluation and the Relationship Between Quality, Satisfaction, and Repurchase Loyalty. Journal of the Academy of Marketing Science. 30, 99-113

34. Rizan, M., Warokka, A., \& Listyawati, D. (2014). Relationship marketing and customer loyalty: do customer satisfaction and customer trust really serve as intervening variables?. Journal of Marketing Research \& Case Studies, 2014, 1.

35. Ozturk, R. (2015). Exploring the Relationship Between Experiential Marketing,Customer Satisfactionand Customer Loyalty, An Emperical Examination in Kenya . Word Academy of Science , Engineering and Technology International Journal of Economic and Managemen Engineering.9, 2817-2820

36. Anwar, S. (2012). Metodologi Penelitian Bisnis.
Jakarta : Salemba Empat.

37. Schmitt, B. (1999). Experiential Marketing. New York : The Free Press New York.

38. Sekaran, U. (1992). Research Methods for Business. Third Edition. Southern Illionis University.

39. Shankar, V., Smith, A. K., \& Rangaswamy, A. (2003). Customer Satisfaction and Loyalty in Online and Offline Environments. International Journal of Research in Marketing, Vol.20 No.2 P.153-175

40. Singh, J., \& Sirdeshmukh, D. (2000). Agency and Trust Mechanisms in Consumer Satisfaction and Loyalty Judgments. Journal of the Academy of Marketing Science, 28. P150-167

41. Smilansky, S. (2009). Experiential Marketing: A Practical Guide to Interactive Brand Experiences. Universitas Indiana : Kogan Page.

42. Sugiyono. (1994). Metode Penelitian Administrasi. Bandung: Alfabeta.

43. Ulfatin, N. (2015). Metode Penelitian Kualitatif Di Bidang Pendidikan: Teori dan Aplikasisnya. Malang: Media Nusa Creative.

44. Utami, C. W. (2006). Manajemen Ritel (Strategi dan Implementasi Ritel Modern). Jakarta: Salemba Empat.

45. Westbrook, R.A., \& Reilly, M.D. (1983). Valuepercept disparity: An alternative to the Disconfirmation-of-expectations Theory of Consumer Satisfaction. Advances in Consumer Research, Vol.10. P.38-44

46. Wijaya. A., \& Subagio. H. (2014). Analisis Pengaruh Experiential Marketing Terhadap Repeat Purchase dengan Customer Satisfaction Sebagai Mediating Variable di De Mandailing Cafe UC Boulevard Surabaya. Jurnal Strategi Pemasaran, 2 (1), P.1-9

47. Wilkie, W. L. (1994). Customer Behavior (Third Edition). New York: Jhon Wiley \& Sons, Inc.

48. Zeithaml, V. A., \& Bitner. (2000). Service Marketing $2^{\text {nd }}$ Edition: Integrating Customer Focus. New York: Mc Graw-Hill Inc. 